\title{
Restructuring UK local government employment relations: pay determination and employee participation in tough times
}

$\underline{\text { Stephen Bach }}$

Alexandra Stroleny

Corresponding Author:

Stephen Bach, Department of Management, King's College London, Franklin-Wilkins Building, 150 Stamford Street, London SE1 9NH, UK. Email: stephen.bach@kcl.ac.uk

\begin{abstract}
The Conservative-led coalition government has been committed to shrinking the state and this has had a major impact on local government. This article examines the consequences of austerity measures for staff participation and pay determination in UK local government. Local government has been particularly hard hit by austerity measures and this has encouraged employers to change terms and conditions, review forms of staff participation and cut jobs. The implications for the institutional resilience of systems of employment regulation and employee involvement in the sector are considered.
\end{abstract}

Keywords Austerity, local government, employee participation, $\underline{\text { crisis, }}$ wage cuts

\section{Introduction}

In the majority of EU countries the public sector has been severely impacted by the consequences of the crisis. Reforms of public service employment relations, influenced by 'new public management' (NPM) ( between public and private sector employment regulation with some decentralization of collective bargaining accompanied by more explicit performance management. These reforms undoubtedly altered the institutions and practice of public sector employment relations in many countries, but rarely as much as proponents suggested, tending to modify rather than transform longstanding state traditions of public sector employment regulation (Bach and Bordogna, 2011; Kickert, 2008).

This picture of institutional resilience, especially in comparison to the private sector, has been challenged by the onset of the crisis from 2008, ushering in an age of austerity (Lodge and Hood, 2012). The public sector across the EU has been characterized as in 'shock' as governments have curtailed the public sector pay bill via a mixture of wage and employment 
cuts. This has strained existing systems of collective bargaining and employee participation (Bach and Bordogna, 2013; Vaughan-Whitehead, 2013).

This article examines developments in UK local government in this era of austerity. As cuts are applied locally, on an authority by authority basis, the local authority is the key level for analysing such activity, albeit within a context shaped by national austerity policies and national bargaining. At individual authority level, two rival propositions can be considered. First, that budgetary cuts have overwhelmed any scope for reaching agreement with the workforce on changes in pay and conditions in the sector. If this proposition is correct we would expect that employers are making little recourse to local employment relations institutions (e.g. joint consultative committees, JCCs) and are unilaterally imposing change on their workforce, with no attempt to consult the workforce. Secondly, by contrast, the depth of cuts may encourage employers to make more use of local employment relations machinery and seek agreement with the workforce to adapt pay and conditions to austerity conditions. We would expect that employers would be reinforcing efforts to consult the workforce and to reach a collective agreement with recognized trade unions rather than impose change.

This article proceeds by examining the traditional model of public sector employment regulation and the implications for staff participation, before examining the role of local government, its workforce and collective bargaining reforms. The ways in which austerity measures have challenged established institutions and practices of staff participation and developments at national and local level are examined.

\section{Local government: structure and workforce}

There are 353 local authorities in England but there is some variation in their structure and functions. There is a broad division between unitary authorities that provide all services and that are concentrated in London and other large Metropolitan areas and two-tier authorities counties and districts - with districts providing more local services within a larger county area. Local authorities are elected bodies but local autonomy is constrained by central government rules that shape local authorities' taxation powers and require them by law to balance their budgets on an annual basis. Central government provides around three-quarters of local authority revenue expenditure with the remainder being raised in the form of a property tax paid by local residents (council tax) and income generated from housing, leisure and other services with strict rules covering the trading activities of local authorities.

Local authorities have responsibility for a wide range of local services of which the largest element (more than half of expenditure) is adult and children's services (NAO, 2013a: 11). Local government also includes: environmental services; cultural and leisure services; highways; housing; planning; and a diminishing portfolio of directly managed schools. Local authorities have a statutory duty to provide key services, including social care, but services such as youth services are discretionary and therefore more vulnerable to budgetary cuts as funding from central government declines. 
The emphasis in current government policy on 'localism' has a hollow feel to it whilst central government controls around 75 per cent of revenue spending and 1335 statutory duties remain in place (Lowndes and Pratchett, 2012; NAO, 2013a: 9). Central government has continually intervened to control council tax increases by limiting local discretion. Consequently local government has been viewed as the poor relation of the public sector in terms of the lack of government recognition of its contribution, unfavourable public expenditure settlements and the extent of central government intervention. This position stems from a legacy of tense central-local government relations, especially during the 1980s (Laffin, 1989), and scope for governments to engage in blame avoidance and blame diffusion strategies (Pierson, 1994).

The largest component of UK public sector employment is in local government. The workforce in its broadest sense - including groups such as teachers and fire officers - is around double the size of the National Health Service (NHS). If groups whose pay is negotiated separately are excluded (e.g. via review bodies), the core local government workforce comprises approximately 1.8 million staff in 2013 (1.275 million full-time employees, FTEs) (Table 2, below). The largest groups comprise school support staff, followed by social care staff and then staff employed working in leisure and cultural services (e.g. libraries) (see LGA, 2011).

Table 1. Shropshire Council: workforce, 2009-2013.*

Table 1. Shropshire Council: workforce, 2009-2013.*

Table 2. Local government employment by headcount, FTE, gender and employment status (England \& Wales).*

Local government is not required to provide all services in-house and a marked shift towards outsourcing occurred in the 1980 s as result of the Conservative government policy of compulsory competitive tendering (CCT). This policy required a wide range of council services to be subject to competition and resulted in job losses, extensive alterations to terms and conditions of employment and radical organizational restructuring (Colling, 1999). The presumption that services should be outsourced was modified by the Labour government's policy of 'Best Value', but overall a substantial proportion of services remain outsourced. It is estimated that contracting out accounts for around half of the $£ 187 \mathrm{bn}$ that the public sector 
spends on goods and services each year (NAO, 2013b). A 2013 survey of 44 councils indicated that 83 per cent outsourced some services, most commonly refuse and street cleaning but also administrative services such as HR and payroll (IDS, 2013).

\section{Collective bargaining and staff participation}

The term social dialogue is not widely used in a UK context, reflecting more adversarial employment relations traditions and a less encompassing role for trade unions and employers in the administration of welfare services. Nonetheless, the UK public sector has been associated with a 'model employer' tradition, comprising an institutionalized and long established system of collective bargaining and employee participation. In local government this tradition has been shaped by the specific features of the sector that has made the national system of industrial relations more fragile than in other parts of the public sector. This stems from the existence of more than 350 separate employers that have jealously guarded their right to decide on most employment matters locally (Kessler, 1991).

Kessler (2005) has characterized the institutionalized approach to participation in the public sector in the UK as having a number of elements. First, a strong collective dimension that operates through a single channel of union representation with extensive collective bargaining coverage. Secondly, a multi-tiered system combining national collective bargaining with local, authority based, joint consultation committees, dealing with the implementation of the national agreement and local issues. This tier has become more important as NPM reforms have fragmented public services and devolved responsibility; a trend reinforced under conditions of austerity. The third component comprises an increased role for direct forms of staff participation.

Local authorities are independent employers but they are voluntarily covered by national-level pay bargaining - the national joint council (NJC) for local government services - that decides on pay and core national conditions whilst providing local authorities with considerable local flexibility and, if they so wish, scope to opt out of national pay bargaining. Employer and trade union negotiating bodies comprise the Local Government Association (LGA) and the main local government trade unions - Unison, GMB and Unite. The LGA coordinates and lobbies on behalf of local government, but it is not the employer and elected councillors, representative of LGA membership, lead negotiations and are often referred to as the national employers. The LGA has to reconcile a variety of different employer interests that are influenced by party politics (Conservative, Liberal, Labour), type of authority (unitary, two-tier), geography (North, South) and locational (urban, rural) interests. This is a complex task especially as the LGA seeks to operate on a consensus basis. Amongst the trade unions, in contrast to other parts of the public sector, there are no clear demarcations in terms of recruitment by occupation, encouraging trade union competition for membership. Unison has the largest local government membership with around 700,000 members.

Both employers and trade unions have questioned the national machinery with employers especially concerned about the perceived rigidity of the system. Trade unions have also 
confronted challenges to national bargaining from below, notably during periods of income policy in the 1970s, when white-collar trade union leaders resisted membership pressure to pursue decentralized collective bargaining. Pressure on national bargaining increased during the 1980s when policies of compulsory competitive tendering resulted in more workplace negotiations (Kessler, 1991). More significant was the requirement to 'equality proof' pay systems against the ongoing risk of equal pay claims by low-paid women workers (Lissenburgh, 1995). Ultimately these pressures resulted in local government being covered by one collective agreement - the National Joint Council [NJC] agreement - referred to as 'single status'. This landmark 1997 agreement was designed to preserve national bargaining but provide local authorities with sufficient flexibility to develop their own pay and grading structures. Basic conditions were harmonized with the NJC agreement (the 'Green Book') including a range of core national conditions (Part 2) such as sick pay, a standard 37-hour week and annual leave whilst Part 3 sets out car allowances, premium and overtime payments that can be varied locally. Implementation of single status locally was very slow, partly because of the absence of additional central government funding. Consequently some authorities were implementing single status more than a decade after the agreement was reached.

Despite reform of bargaining structures, approximately 15 per cent of councils (around 45), located in the south east of England, have opted out of national pay bargaining and determine their annual pay award locally. This occurred mainly in the late 1980s and early 1990s in response to recruitment and retention difficulties with the establishment of local pay scales positioned above NJC levels. In practice, prior to austerity, many of these councils applied the national award to their pay scales (IDS, 2012).

The second characteristic comprises the multi-tiered nature of participation. In addition to national collective bargaining structures, at individual employer level, joint consultative committees (JCC) exist. They are established on a voluntary basis, comprising employer and employee representatives and, in local government, elected councillors. JCCs in the past tended to focus on non-pay matters such as agreeing local disciplinary and other procedures and acted as a forum for employers to communicate their plans and consult with local trade union representatives (Laffin, 1989). JCCs have been confronted with contradictory pressures. On the one hand, they operate in a situation in which trade union membership is declining and HR managers are concerned to involve the whole workforce, not only trade union members. On the other hand, senior management and HR strategies are centrally concerned with making decisions at local level and maintaining staff awareness of the challenging context faced by local authorities, especially in the context of a lengthy pay freeze (CIPD, 2012).

Local authorities have revamped their JCC arrangements to focus on a smaller number of strategic issues, retitled them and established additional voice mechanisms. For example, Shropshire County Council has a JCC but also established a workforce-wide staff forum to assist in consultation over changes in terms and conditions.

The third component is an increase in direct participation, increasingly geared towards improving service delivery and to facilitate changes in rewards, HR practice and ways of 
working. Most councils have developed dense systems of management-led employee involvement that may be more immediately visible to staff than traditional forms of joint consultation. Although not mandatory, virtually all councils use regular (annual/biannual) staff opinion surveys, focus groups, road-shows of senior directors, team briefings, newsletters, 'frequently asked questions' on their intranets etc. This growth is evident from the 2011 WERS data that indicate a further increase in public sector direct communication and involvement whilst the presence of JCCs is in decline (Van Wanrooy et al., 2013).

This growth has occurred in a period when public sector trade union density has decreased from 61.2 per cent to 56.3 per cent between 2007 and 2012 (Department for Business, Innovation and Skills, 2013). This trend is being reinforced by public sector job losses, encouraging employers to supplement single channel, union-based, participation. Birmingham City Council (2011: 3), the largest local authority in the UK, stated in its review of relations with its trade unions that it would be beneficial 'to look at ways to extend the way it conducts consultation and negotiation to allow non-unionized employees the voice that many stated they would like'. The consequences for trade union influence have been highlighted by Unison (2011: 1) in a report to its 2011 conference:

'One of the major challenges we face in local government and the health service is the continuing fall in trade union density. Our credibility with employers and government as well as our national and local bargaining strength are at stake if we do not tackle this issue in what are our traditionally strong membership areas.'

\section{Local government under austerity}

\section{Conservative coalition policy}

In 2010, the Labour government was replaced by a Conservative-led coalition government committed to fiscal consolidation as part of its programme to shrink the state and to address the deficit that had increased greatly as a result of government expenditure to support the banking and finance sector. The coalition agreement stated that 'deficit reduction and continuing to ensure economic recovery, is the most urgent issue facing Britain' (Cabinet Office, 2010: 15). In the 2010 spending review a target was set to reduce the deficit from 8.4 per cent of GDP in 2009 to 0.4 per cent by 2015 with three-quarters of deficit reduction linked to public spending cuts of $£ 81$ bn (total government expenditure in 2010-2011 was $£ 697 \mathrm{bn}$ ) (Treasury, 2010). Government departmental expenditure will fall by 18.6 per cent in real terms by 2017-2018, with major consequences for public sector pay and employment (IFS, 2013).

The political ideology and underlying economic assumptions of the coalition government constitute important drivers of unprecedented public expenditure reductions. The starting point is criticism of the previous Labour government's expansion of 'big government', requiring 'social responsibility not state control; the Big Society not big government' (Conservative Party, 2010: 35). There are also, however, continuities with the Labour government's policy of encouraging diverse service provision and marketization. Large-scale privatization has been 
revived with the (partial) privatization of Royal Mail and the probation service and around a quarter of councils are looking to further outsourcing, but outsourcing via 'shared services' with neighbouring authorities is more prevalent ( $\underline{\mathrm{RSA}, 2012})$.

Local government is bearing a disproportionate proportion of expenditure reductions as compared to higher priority services such as the NHS. The Treasury in the 2010 spending review indicated that central government funding to local government would fall by around 27 per cent between 2011-2012 and 2014-2015 in real terms from £29.7bn to £22.1bn (NAO, 2013a). Importantly these reductions were 'front-loaded' with the steepest reductions during the period 2011-2013. Additional expenditure reductions of $£ 445 \mathrm{~m}$ for $2014-2015$ were unveiled in Autumn 2012 supplemented in June 2013 with additional expenditure cuts for 2015-2016, comprising a total reduction in central government grant of in excess of 30 per cent. The LGA's 'graph of doom' suggests that after social care and waste services are accounted for other services face a 90 per cent cut in expenditure, leaving them unsustainable and making local authorities vulnerable to legal challenges (LGA, 2012: 10). Within this bleak financial context there are significant variations in the circumstances of individual local authorities, with reductions in budgets systematically greater in more deprived local authorities, attributed to the removal of specific government grants that supported less affluent areas (Hastings et al., 2013).

The coalition government is pursuing a policy of deinstitutionalization, whereby many of the institutions built up during Labour's period of government which supported workforce modernization are being abolished or merged, accompanied by substantial job losses (Bach and Kessler, 2012). An important component of this process has been a questioning of the utility of national pay determination. The objective is to make public sector wages more sensitive to local labour market conditions, intended to lower them in lower-cost areas. This policy stems from the coalition government's assertion that: 'the overall value of the public sector reward package, including pension provision, has been generous in recent years' (Treasury, 2010: 37). The coalition government has therefore targeted the pay bill by: pension reform, wage restraint, including changes to pay and conditions, and staffing reductions.

\section{Austerity: measures and consequences}

Public sector pensions have been portrayed as overly generous although the government's pension inquiry "firmly rejected the claim that current public sector pensions are "gold plated", (Hutton, 2011: 26). In terms of the public sector it recommended that: pensions should be indexed and uprated in line with a lower (Consumer Price Index) measure of inflation; normal pension age should move in steps from 65 to 68; workers' contributions should be increased with the highest earners facing the largest percentage increases; and schemes should switch from final salary based schemes to career average based schemes with accrued rights protected. Following industrial action across the public sector in November 2011, Hutton's recommendations formed the basis of intensive negotiations and agreement between the LGA and local government trade unions that were accepted by Unison, GMB and Unite in membership ballots, indicating the scope for effective joint working on complex and 
contentious issues. An important component of the agreement was that when staff are subject to a non-voluntary transfer of employment (e.g. due to outsourcing) they will have the right to stay in the local government pension scheme, a major victory for local government trade unions as TUPE (Transfer of Undertakings [Protection of Employment] Regulations 2006) does not cover pension rights.

In terms of wage restraint, an emergency budget in June 2010 announced a two-year wage freeze (2011-2013) with some protection for staff earning $£ 21,000$ or less, subsequently followed by two years when pay awards were limited to an average 1 per cent. The position of local government is distinctive. In central government (including the NHS) pay review bodies have become more important in pay determination over recent decades, providing the government with scope to intervene directly by accepting, modifying or rejecting pay review body recommendations. In local government, central government is involved indirectly in pay determination via its expenditure decisions and local government is therefore not within the remit of the government's public sector pay policy. This has resulted in a lengthier (20102013) period of pay restraint. Local government employers awarded no pay increase in 2010, before the coalition government decided to impose a two-year pay freeze, and declined to follow central government and provide a $£ 250$ pay increase for the lowest paid. Two further years of no pay offer followed in 2011 and 2012 with national employers stating that: 'There is genuine sympathy for the position of the lower-paid but... any pay award could only be met through further job losses and cuts to services' (cited in IDS, 2012).

The LGA is in a difficult position. It is dominated by Conservative councils, of differing ideological hues, with some harbouring reservations about the severity of cuts. At the same time there is an institutional interest in maintaining its relevance as an employers' organization underpinned by the national agreement, but this is difficult when national pay bargaining has been in abeyance for three years. Trade unions recognize that employers are seeking to amend core national conditions, despite considerable local flexibility. A dilemma for trade unions is that in the absence of sector-wide reform and with a lengthy pay freeze, the focus has been on local-level negotiations, usually involving unpalatable trade-offs between pay, conditions and employment, eroding the national agreement.

The national employers signalled they would seek to make a pay award in 2013, in exchange for changes in national terms and conditions. The 2013 negotiations resulted in a 1 per cent pay increase, endorsed by trade union membership ballots in Unison and the GMB (but not Unite). The national employers, however, were 'extremely disappointed that the unions have been unable to consider even the most minor elements of reform' (LGA, 2013a). In practice, scope for reforms of core conditions at national level was challenging for employers as well as trade unions. Local variations in core national conditions, such as reductions in sick pay or annual leave, have been implemented by some authorities and these employers were concerned that they would be paying for change twice - locally and nationally.

This impasse has encouraged a different employer approach for 2014-2015 with implications for the level at which change is negotiated; the substantive content of reform and the process 
by which this will be achieved. The LGA is working with local authorities to achieve change locally rather than nationally, with a focus on existing core national conditions such as sick pay, annual leave and length of the working week, leaving national negotiations to focus on pay. This process diminishes further the regulatory influence of the national agreement with the LGA effectively abandoning attempts to get reform at national level and supporting local change. It confirms the difficulties faced by local government trade unions in maintaining opposition to local negotiations on national (Part 2) core conditions. Local government trade unions nationally have always instructed local branches not to negotiate on these conditions and to register disputes. Some local authorities have removed contentious changes in sick pay from austerity-driven workforce packages, but many others have proceeded with them (LGA, 2012). Substantial job losses have made the threat of employment cuts very tangible, leading local trade unions to consider cuts in sick pay to forestall larger employment reductions or to accept the suspension of incremental progression. These changes on a temporary or more permanent basis reinforce uncertainty about the future of national bargaining. A small majority (52 per cent) of local authorities expect it to continue at least in the short term, many expect the break-up of national bargaining or at the very least expect it to become confined to pay rather than conditions (IDS, 2013).

A survey of 224 councils conducted by the LGA in December 2010 and then repeated in September 2011 identified a high level of local activity designed to generate short-term savings (LGA, 2012: 10-11 and see Grimshaw et al., 2012). Over half of local authorities had reduced car allowances whilst around a quarter were changing their sick pay schemes, removing payments for the first two or three days of absence, although this may reduce the incentive to return to work. Other changes being implemented included reductions in annual leave, premium pay rates - such as at weekends or public holidays - and overtime, unsocial hours payments and 17 per cent were considering the removal of increments (11 per cent had already removed them). This figure had increased to around 20 per cent by 2013 accompanied by movement towards performance-related progression pay, linked to individual appraisal or competencies (LGA, 2013b). Although local employers are focused on curtailing their pay bills, they are also aware of the need to consider recruitment and retention issues and their role as an employer in tackling disadvantage, encouraging many employers to become a living wage employer. In contrast to the statutory national minimum wage (NMW) the living wage is voluntary. The hourly rate is set at a higher level than the minimum wage and is calculated to reflect the basic cost of living in the UK. The 2013 London Living wage is $£ 8.80$ ( $£ 7.65$ outside London) compared to the adult NMW rate of $£ 6.31$.

\section{Staff participation in changes to pay and conditions}

In terms of the process of reform, around 27 per cent of local authorities stated that changes were being considered by trade unions, 37 per cent had not shared their plans with the unions, 23 per cent had reached agreement with them (although this was often linked to single status rather than budget cuts) and 4 per cent had imposed change or planned to do so (LGA, 2012). Although the percentage imposing change is small, this figure does not include employers that have used the threat of unilateral cuts in terms and conditions to gain agreement. Although not 
common, high-profile cases signal to the local government workforce that unilateral change is not a hollow threat. Section 188 of the Trade Union and Labour Relations (Consolidation) Act 1992 allows employers to give notice and lawfully dismiss workers and re-engage them on new contracts with different terms and conditions, provided attempts have been made to reach agreement and a period of consultation has occurred. In this context staff are under considerable duress to agree to the new contract to prevent dismissal.

For trade unions and their members this represents a difficult situation because the inability to prevent unilateral imposition - if staff are dismissed and re-engaged - indicates a limited capacity to influence change locally. Most local government employers have recognized the considerable risks to staff engagement and the detrimental effects on employment relations of imposing change unilaterally, using a process of dismissal and re-engagement. In several highprofile cases, such as Southampton City Council, unilateral wage cuts provoked rolling strike action by different groups of workers and legal challenges. These actions did not prevent the imposition of new contracts in 2011 and associated wage cuts, although the employer did make some concessions in comparison to the original proposals. Other high-profile cases include Shropshire Council and Birmingham City Council. The threat of dismissal and re-engagement has therefore been more widely used as a negotiating strategy; putting pressure on individual employees to accept new terms or force the trade unions to reach a local collective agreement for the whole workforce.

Take the case of Shropshire Council (established by reorganization in 2009), a Conservativecontrolled unitary council, with a workforce of almost 8000 FTEs of which around 35 per cent are Unison members. It set a savings target of $£ 76 m$ to be achieved by 2013/14. During 2010/11 proposals were outlined to change terms and conditions that the council argued would save around $£ 7 \mathrm{~m}$ and safeguard 400 jobs. The proposals included a pay reduction for all staff of 5.4 per cent but with partial exemption for the lowest paid, retention of market supplements for hard to recruit groups, and changes to sick pay and car mileage allowances. The council proceeded with its threat to dismiss and re-engage staff as no collective agreement was agreed, despite protests and Unison members taking 24-hour strike action. The planned 5.4 per cent pay reduction was phased over two years with a pay cut of 2.7 per cent implemented from October 2011. The proposed 2.7 per cent cut from October 2012 was reduced for most staff to 1.7 per cent following consultations with trade unions and the workforce. In addition, during 2011 the Council removed payment for the first three days that staff were sick, but in November 2012 reversed this policy agreeing to work with trade unions to reduce absenteeism. The process blended coercion and consultation with trade unions and the wider workforce. Pay cuts, however, have not prevented employment reductions and in 2013 Shropshire Council announced plans to make 1700 redundancies as part of moves towards halving its workforce by 2015 to address funding reductions and to shift towards a commissioning-led authority (BBC, 2011a and b; Shropshire Council, 2011; Shropshire Star, 2013). Job losses have deepened since 2010-2011 (see Table 1).

Even in very inauspicious circumstances local trade unions have played a significant role in modifying employer proposals, suggesting that trade unions still have some capacity to 
recalibrate employer strategies. Trade union capacity to mobilize, however, is constrained by existing legal constraints and fear of job loss as well as often low turnouts and slim majorities in ballots for industrial action. A further threat arises from the coalition government encouraging local authorities to reduce paid time that staff representatives are granted to undertake trade union activities. It remains uncertain, however, if there is much appetite amongst employers to antagonize further the workforce in a period of rapid change. As the LGA points out in advice to its members 'reasonable facilities are important. There is considerable value in coherent and timely trade union input in dealing with significant organizational change and when terms and conditions are being re-negotiated' (LGA, 2013b: $10)$.

\section{Employment reductions}

The most significant response to austerity has taken the form of employment cuts. In contrast to the 'sovereign employer' tradition, there is no separate public sector employment statute in the UK, placing relatively few constraints on collective dismissals as long as appropriate consultation procedures are followed, including attempts to minimize redundancies. Individual employment protection has been reduced further because the coalition increased the qualifying period for protection from unfair dismissal from one to two years and introduced fees for tribunal hearings. The scale of workforce reductions in a short time period is unprecedented. The Office of Budget Responsibility (OBR) initially predicted in June 2010 that public sector employment would decline by 490,000 jobs by $2014-2015$ but this forecast has been increased several times and the OBR suggests that 730,000 jobs, around 13 per cent of general government employment, will be removed by 2016-2017 (BR, 2012). Local government has been most affected by employment reductions.

Table 2 indicates that employment reductions between 2008 and 2013 in England and Wales have amounted to almost 429,000 staff (295,000 FTEs), 19.3 per cent of the local government workforce (18.8 per cent in FTEs) - almost one in five. This decrease in FTEs is particularly evident since 2010, when austerity measures started in earnest. Up to early 2010 the number of FTEs in local government had increased, reflecting the overall growth in employment in the public sector as a whole under Labour (1997-2010). What these data do not indicate, however, is the variety of means by which these workforce reductions are being implemented. In many cases local authorities are combining vacancy freezes, mainly voluntary redundancies, and delayering with more concerted efforts to share services. At least 337 local authorities in England are sharing services such as HR (LGA, 2013b). In addition, services are also being withdrawn, more narrowly targeted or downgraded, as the case of libraries illustrates (House of Commons, 2013).

The breakdown of trends by gender and employment status provides a more detailed picture and indicates that temporary and agency staff are often being particularly targeted given that employment reductions within this category amount to 22 per cent, whilst the proportional decrease in permanent staff is lower at 18.8 per cent. Table 2 also highlights the high proportion of women in the workforce with a much higher proportion of part-time as well as full-time staff 
being female. Overall, three-quarters of staff employed by local authorities are women (2010: $75.1 \%$ ) and consequently austerity measures are having a disproportionate effect on women. However, there do not appear to be significant gender differences in the proportion in which employment levels fell in local government: there has been a reduction of around 15 per cent for both male and female part-timers respectively, and only a slightly higher reduction in male full-timers of around 24.8 per cent compared to a decrease of 22.2 per cent of female fulltimers. However, in terms of total headcount, female staff, especially part-time staff, are bearing the brunt of job losses.

\section{Conclusion}

Local government has been particularly hard hit by austerity measures and the traditional model of employment regulation provided considerable scope for employers to alter terms and conditions and reduce employment in comparison to local government in many other countries where staff are governed by stricter legal statutes. The centrality of national collective bargaining and arrangements for local staff participation has not precluded vigorous debate about the most appropriate balance between national and local decision-making and over the type of issues that should be decided at local level. Consequently there has always been a degree of fragility in relation to the national bargaining structure, reflecting the existence of over 350 independent employers with diverse political and economic circumstances and employing a differentiated workforce. Nonetheless, despite some caveats, especially in relation to low-paid women workers, the model employer approach in the past provided safeguards for the workforce via an institutionalized system of employee participation grounded in high trade union density, national collective bargaining and systems of local consultation.

Our analysis indicates that in local government the institutional embeddedness of national pay determination has decreased with the role of the national agreement as a mechanism that sets core national standards across the sector in retreat. Most local authorities continue to see value in some form of national pay coordination, but they have reasserted their right to decide locally key terms and conditions of employment, blurring the division between terms that are agreed locally and those that are agreed nationally. This, however, is far removed from the coalition government's vision of deinstitutionalized employment relations with market-facing pay and a restricted role for collective, trade union-based voice. There is little evidence that more employers are seeking to opt out of the national agreement or to restrict the role of trade unions. Oxford City Council is one high-profile authority that has opted out of the national agreement since the start of austerity cuts, but it has not triggered further exit from the national agreement. In some ways the preoccupation with the national agreement and its future directs attention away from important developments that are occurring at local authority level.

In relation to our two propositions, austerity has not overwhelmed the scope for trade union and employee participation in responding to change. At national level there are signs of such a trend as central government instigated unilaterally a pay freeze. Although it did not cover local government it set the parameters for negotiations within the sector. The pay freeze, however, and the scale of cuts has galvanized employers to seek local agreement for changes in terms 
and conditions and this can rarely be achieved without trade union involvement. These forms of concession bargaining have been very challenging for trade unions. They have increasingly confronted employers that have engaged in widespread face-to-face consultation with the whole workforce that has influenced the stance of local employers and trade unions. Local employers have therefore attempted to maintain workforce engagement and this has combined traditional representative participation via trade unions and intensive processes of communication, directly to staff. Consequently our second proposition that austerity measures have encouraged more staff participation is a more prevalent response across the local government sector. This participation, however, is relatively shallow and very much on terms set by the employer. Trade unions remain in a highly defensive concession bargaining position that provides little encouragement for local government trade unions as they seek to rebuild or at least stabilize membership losses incurred under continuing conditions of austerity.

\section{Funding}

We acknowledge the financial support of the European Commission under the EU-financed project 'Social Dialogue and the Public Services in the Aftermath of the Economic Crisis: Strengthening Partnerships in an Era of Austerity’ [grant number VS/2011/0412]. 